\title{
Lactic Acid Bacteria With Antimicrobial Properties Isolated From The Intestines of Japanese Quail (Coturnix Coturnix Japonica)
}

Amni Nadhirah Abdullah Pirus, Azzmer Azzar Abdul Hamid, Tengku Haziyamin Tengku Abdul Hamid*

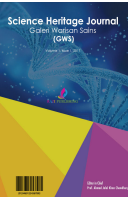

Department of Biotechnology, Kulliyyah of Science, International Islamic University Malaysia, Jalan Sultan Ahmad Shah, Bandar Indera Mč hkota, 2520(। Kuantan, Pahang *Corresponding author: haziyamin@iium.edu.my

This is an open access article distributed under the Creative Commons Attribution License, which permits unrestricted use, distribution, and reproduction in any medium, provided the original work is properly cited

\section{ARTICLE DETAILS}

\section{Article history:}

Received 27 September 2016 Accepted 13 December 2016 Available online 10 January 2017

Keywords:

Lactic acid bacteria, quail intestine probiotics, enterococcus

\section{ABSTRACT}

Lactic acid bacteria (LAB) confer many advantages to humans and animals and they provide natural protection against bacterial pathogens such as Salmonella typhymurium and Eschericia coli. LAB strains have been isolated from various animal sources but from this research LAB were isolated from quail's (Coturnix coturnix Japonica) intestine. About 12 strains were isolated from the quail's intestine; and out of these, 5 samples (S1-1B, S2-1A, S2$1 \mathrm{~B}, \mathrm{~S} 2-2 \mathrm{~B}$ and S3-1A) produced lactose on lactose test. All of these strains appeared to be non-motile coccus with gram positive morphology, catalase-negative and oxidase-negative. These strains showed antimicrobial activities (inhibition zones) against indicator bacterium, i.e., Staphylococcus aureus, Escherichia coli and Salmonella typhimurium using agar well methods. PCR amplification of $16 \mathrm{~S}$ ribosomal RNA revealed that these five isolates show highest sequence similarity with other LAB strains isolated from other animals which include common genera such as Enterococcus and Lactobacillus. Strain S1-1B, S2-1B and S2-2B were highly similar with Enterococcus faecium, strain S3-2B with Enterococcus durans and S2-1A with Lactobacillus salivarius. This work shows that common LAB species were isolated from intestinal tissues of Malaysian quail (Coturnix Japonica) which were able to produce antimicrobial activities against pathogenic strains.

\section{INTRODUCTION}

In Malaysia, Coturnix cortunix japonica is the common species of quail that is used commercially for meat and egg production [1]. Since 1995, in Malaysia alone the demand for quail is reported to increase at 20-25\% per year [2] Other than poultry, quail has played many important roles in industry and research as it has small size, low husbandry costs, short generation interval and adaptability to a wide range of husbandry conditions [3]. As they it is easy to handle, it has been commercialized widely in farming industries providing developing countries with a stable source for alternative animal proteins. Quail contains high protein content in its digestive tract in which specific epithelial cells secrete mucus, protecting it from pathogenic bacteria [4]. However, similar to poultry, quail is also vulnerable to gastrointestinal disease involving esophagus, stomach, small and large intestines. In order to meet the growing demand, large scale quail production will require good fertility, hatchability and healthy chicks [5].

The use of antibiotic in animal feeding has resulted in the emergence of antibiotic resistance bacteria. Probiotic such as Lactic acid bacteria (LAB) can be a useful substitute that can also benefit animal growth and disease resistance. $\mathrm{LAB}$ typically are organotrophic, and a strictly fermentative gram-positive rod or coccus, non-spore former, catalase negative, aerotolerant, acid tolerant, producing lactic acid as a major end product. LAB are recognized as GRAS (Generally Recognized as Safe) and they are commonly used as starter culture in many traditionally fermented foods of many countries. LAB consist of various genera of which some of these are recognized as probiotics, such as Lactobacillus, Lactococcus, Enterococcus, Carnobacterium, Streptococcus and Bifidobacterium. Since some of LAB are able to transfer multidrug resistance gene [6], assigning of all LAB genera into potential probiotic are widely debated. Consequently, a detailed characterization on the safety use of LAB species remains a subject of intense research. There are many studies reported on the beneficial use of certain LAB strains in animal feeding. For instance, the use of probiotic from strain Lactobacilus fermentum AD1 resulted in 14\% weight gain in Japanese quail [7]. In addition to our previous works on LAB screening from various local sources such as fermented food [8], broiler chicken [9], rabbit [10] and catfishes [11]; this work reports on several LAB strains isolated from quail's intestine with the objective to identify the diversity of LABs in quail. Future exploration of this LABs as well as the antimicrobials they produce would enable their uses as probiotic sources for quails or poultry feeding. 2. EXPERIMENTAL

Several 15 to 20 days old quails (Coturnix coturnix japonica) were purchased from local farmers near Jerteh, in the state of Terenganu, Malaysia. Three quails were slaughtered and the gastrointestinal tract (GIT) was dissected and weighed. Each intestinal tissues was chopped and labeled. These samples were dispensed $(\sim 5 \mathrm{~g}$ each) into a universal bottle with $5 \mathrm{ml}$ nutrient broth and vortexed. Two folds of serial dilution were done to each sample using MRS broth, and $100 \mu \mathrm{l}$ of each dilution was spread on MRS agar and incubated at $37^{\circ} \mathrm{C}$ for 48 hours under anaerobic condition using anaerobic jar. Single colony appeared was picked up and sub-cultured on MRS agar. Colonies were propagated on MRS medium, and the stock culture (glycerol 80\%) were prepared until further use. The lactose test and other standard biochemical test such as catalase, oxidase, and motility tests were carried out on each isolated strain.

All five lactic acid bacteria samples were tested for their antimicrobial activities by agar well diffusion method using three indicator strains, i.e. Staphylococcus aureus, Salmonella typhimurium and Escherichia coli. For negative control, the nutrient broth was used. The inhibition zones were measured (in $\mathrm{mm}$ ) and the results were the mean of the duplicates.

PCR amplification was performed for $16 \mathrm{~S}$ ribosomal RNA gene using universal primer. Genomic DNA was extracted from all isolates using GF-1 DNA Extraction kit (Vivantis). PCR amplification using universal primer for 16S rRNA gene was 5'- AGA GTT TGA TCC TGG CTC AG - 3' (for forward) and 5'- AAG GAG GTG ATC CAG CCG CA - 3' (for reverse). The gene amplification was carried out in total a volume of $50 \mu$ reaction mixture containing $1 \mu \mathrm{l}$ template DNA (10ng), $1 \mu \mathrm{l}$ dNTPs (10mM), $5 \mu \mathrm{l} 5 \mathrm{x}$ PCR buffer, $0.5 \mu \mathrm{l}$ Taq DNA polymerase, and $1.0 \mu \mathrm{l}$ of each primer. PCR amplification (Mastercycle, Germany) was done with initial denaturation $\left(94^{\circ} \mathrm{C}, 2 \mathrm{~min}\right)$ followed by 25 cycle of denaturation $\left(94^{\circ} \mathrm{C}, 1 \mathrm{~min}\right)$, annealing $\left(55^{\circ} \mathrm{C}, 1\right.$ minute) and extension $\left(72^{\circ} \mathrm{C}, 1 \mathrm{~min}\right)$ and this was followed by a final extension $\left(72^{\circ} \mathrm{C}, 10\right.$ min). PCR products were analyzed by $1 \%$ agarose gel electrophoresis. The result of DNA migration within the gel electrophoresis was viewed under UV light and photographed using Gel Documenter (AlphaImager ${ }^{\mathrm{TM}} 2200$ ). PCR product for each sample was subjected to sequencing (1st Base Laboratory, Malaysia). The DNA sequences were edited, trimmed to remove noise and aligned before being analyzed for similarity by using BLASTN search tool (NCBI). The sequences were also used for phylogenetic analysis, in which the evolutionary history was inferred using neighbor-joining method. The phylogenetic tree was computed using software MEGA 6.0. 3. RESULTS AND DISCUSSION

From this work, a total of $12 \mathrm{LAB}$ strains were isolated from quail intestines. Out of these, only 5 strains (S1-1B, S2-1A, S2-1B, S2-2B and S3-2B) were found to be lactose positive on lactose agar medium, both catalase and oxidase negative as well as lack of motility (see Table 1). Beside gram positive cocci morphology, these isolates shares all other common biochemical test features exhibited by LAB. On agar well diffusion test, all isolates showed 
zones of inhibition against the three indicator strains, I.e., Escherichia coli, Staphylococcus aureus and Salmonella thyphimurium. As shown in Figure 1 , the sizes of inhibition ranged between $12.0 \mathrm{~mm}$ to $15.0 \mathrm{~mm}$ (see also table 2). Isolate $\mathrm{S} 2-1 \mathrm{~A}$ recorded the highest inhibition of $15.0 \mathrm{~mm}$. For all of these strains, $\mathrm{NaOH}$ neutralised cell supernantants were able retained these inhibitive properties, and this indicated that the inhibitions were not due to acid produced by the bacteria. The antimicrobial action of LAB is mainly due to various factors including the production of metabolites such as organic acids (lactic and acetic acid), hydrogen peroxide, ethanol, diacetyl, acetaldehyde, acetoine, carbon dioxide, reuterin, reutericyclin and bacteriocins [12]. Bacteriocin or small peptides usually produced by LABs antagonises closely related gram positive bacteria. Further tests will be required to confirm if the inhibitory compounds are protein or peptides. Based on rRNA sequencing, three of 4 isolates, S1-1B, S2-1B, S2-2B and S32B showed highest similarity with Enterococcus sp.; namely Enterococcus faecium and Enterococcus durans. Among LAB, Enterococcus sp are the most ubiquitous in terms of habitats, and this genera are very common for bacteriocinogenic activities against Listeria moncytogenes. These were also frequently identified species from poultry fecal samples [13]. Enterococcus faecium is a commensal bacterium of human and animal gastrointestinal tract and it is commonly implicated as nosocomial pathogen. Its ability to develop resistance to multiple antibiotics, including vancomycin is an emerging treat to human health [14]. However, many benefits of using Enterococcus sp. as probiotics source are continously being reported. Enterococcus faecium strains isolated from Thai native chickens showed better performances in acid and bile tolerance, intestinal mucus attachment, pathogenic bacterial inhibition, and bacteriocin production [15]. Meanwhile, Enterococci isolated from the crop and caecum of Japanese quails were subjected to storage studies [3]. Meanwhile, Enterococcus durans, a gram positive and non-motile bacteria was isolated from human, veterinary or clinical materials, and also from food and the environment. However, compared to Ent. faecium, Ent. durans is a rare opportunistic pathogen.

Isolate $\mathrm{S} 2-1 \mathrm{~A}$ possess the highest sequence similarity with Lactobacillus salivarius. This LAB strain showed to have high adhesion capacity to intestinal cell lines of chicken and ducks, a desirable properties of probiotic [16]. Lactobacillus salivarius strain UCC118 was isolated from the ileal-cecal region of an adult and it has a spectrum of probiotic features, such as resistance to acid and bile [17]. Studies on chicken microbiota found that Lactobacillus salivarius, Lactobacillus reuteri, and Lactobacillus acidophilus occupied the crop and these species were existing throughout the chicken digestive tract [18]. This strain exhibited promising therapeutic potential and administration of Lactobacillus salivarius had successfully influenced the gastrointestinal flora, attenuate inflammation, and reduced neoplastic lesions in knockout mice [19]. This strain also produces a potent broad-spectrum class II bacteriocin Abp118 which is active against Listeria monocytogenes, an invasive foodborne pathogen. Genus Lactobacillus is highly desirable for modern food and feed technologies as it has commercial probiotic value [20].
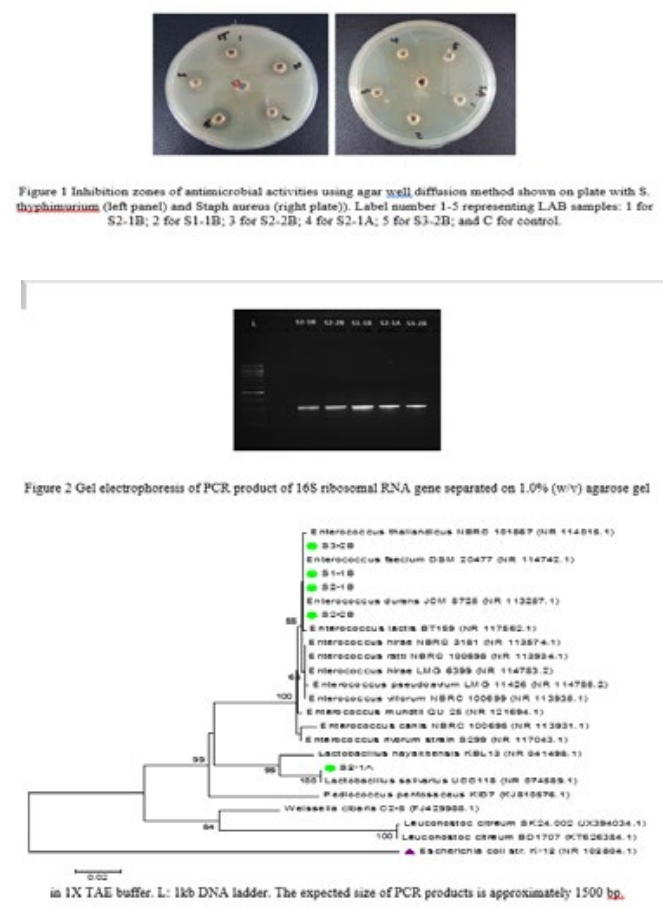

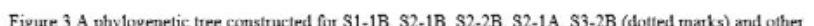
closely related Enterococcus and $\mathrm{L}$ actobacillus strains based on $16 \mathrm{~S}$ rRNA, gene sequence comparisons. Scale bar cquals 0.02 substitutions per nucleotidc. Bootstrap values (\%) are indicated at the branches from 1000 replications. The sequence of Escherichia coli stain $\mathrm{K}-12$ was used as an outgroup.

Table 1 Biochemical and morphological tests for five LABs isolates

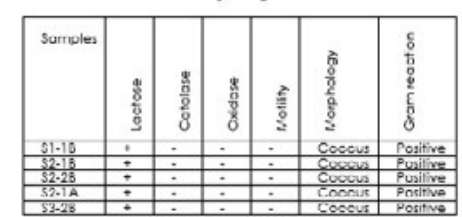

\begin{tabular}{|c|c|c|c|}
\hline \multirow{2}{*}{ Somplins } & \multicolumn{3}{|c|}{7 7one of inhibilion (Diameler in mm) } \\
\hline & E. coll & 5. typnimunum & 5. aureus \\
\hline $51-18$ & 13.5 & 13.0 & 13.0 \\
\hline $52-18$ & 11.0 & 12.5 & 13.0 \\
\hline $52-28$ & 13.5 & 120 & 10.0 \\
\hline \$2-1A & 15.0 & 15.0 & 13.0 \\
\hline $53-28$ & 14.0 & 11.5 & 13.0 \\
\hline
\end{tabular}

Based on phylogenetic tree constructed as shown on Figure 3, samples S32B, S1-1B, S2-1B and S2-2B are clustered together in a branch, but separated from $\mathrm{S} 2-1 \mathrm{~A}$ which is clustered with Lactobacillus salivarius. Enterococcus faecium, Enterococcus durans and Lactobacillus salivarius belong to the same clade which is further connected to other clades containing other gram positive bacteria Pediococcus pentosaceus, Weissella cibaria and Leuconostoc citreum, . These bacteria are all belonged to phylum Firmicutes, class Bacilli and order Lactobacillales.

\section{CONCLUSIONS}

In this work, five LAB strains were successfully isolated from intestines of Malaysian quails. These strains belong to common genera of LABs frequently isolated from other animals such as Enterococcus sp. and Lactobacillus sp. These strains were all demonstrated antibacterial activities against gram positive pathogenic bacterium such as Staphylococcus aureus and gram negative bacterium such as Escherichia coli, and Salmonella thyphimurium. Future characterization on the antibacterial component produced from these strains will enhance their uses as potential probiotic sources for animal and antibacterial agents.

\section{Acknowledgement}

The authors wish to thank IIUM and Ministry of Higher Education, Malaysia for support on this work.

\section{References}

1. Seet, C.P.A.A., M.D., Growth Performance and Carcass Characteristics of

Japanese Quail In Malaysia. MARDI Res. Bull., 1987. 15(1): p. 55-58.

2. RBI Quail production boost in Malaysia and abroad. World Poultry, 2009.

3. Lauková, A. and G. Michlovičová, Enterococci isolated from Japanese quails exposed to microgravity conditions and stability of their properties. . Acta Veterinaria Brno., 2009. 78: p. 253-258.

4. Ardyati, T., et al., B2-5 (Coturnix Japonica) Tractus Digestivus and Their Potency To Inhibit Growth of Salmonella Typhimurium, 2005: p. 978-979.

5. Othman, R.A.A., M .R. and Rahman, S., Effect of egg size, age of hen and storage period on fertility, hatchability,embryo mortality and chick malformations in eggs of japanese quail (Coturnix coturnix japonica). IOSR Journal of Agriculture and Veterinary Science 2014. 7(1): p. 101-106.

6. Lund, B. and C. Edlund, Probiotic Enterococcus faecium Strain Is a Possible Recipient of the vanA Gene Cluster. Clinical Infectious Diseases: 2001. 32: p. 1384-1385.

7. Strompfova, V., Marcinakova M., Gancarcikova, S., Jonecova, Z., Scirankova, L., Guba, P., Koscova, J.,Boldizarova., K., and Laukova, A., New probiotic strain Lactobacillus fermentum AD1 and its effect in Japanese quail. Vet. Med. - Czech., 2005. 50(9): p. 415-420

8. Hajar, S. and T.H.T.A. Hamid, Isolation of lactic acid bacteria strain Staphylococcus piscifermentans from Malaysian traditional fermented shrimp cincaluk. International Food Research Journal 2013. 20(1): p. 125129. 
9. Yusuf, M.A. and T.H.T.A. Hamid, Isolation of coagulase negative Enterococcous sp. strains from non-broiler chicken producing bacteriocin active against Staphylococcus aureus. Journal of Agrobiology, 2013. 30(1): p. 33-42.

10. Hamid, T.H.T.A. and M. F.A., The Isolation and Characterization of Coagulase-negative Staphylococcus spp. from Intestine of a Malaysian Rabbit (Oryctolagus cuniculus). Borneo J. Resour. Sci. Tech., 2012. 2: p. 41 45 .

11. Hamid T.H.A, et al., Isolation and screening of lactic acid bacteria,Lactococcus lactis from Clarias gariepinus (African catfish) with potential use as probiotic in aquaculture. African Journal of Biotechnology 2012. 11(29): p. 7494-7499.

12. Suskovic, J., et al., Antimicrobial Activity of Lactic Acid Bacteria Food Technol. Biotech., 2011. 48: p. 296-307.

13. Strompfová V, Lauková A, and M. D, Effect of bacteriocin-like substance produced by Enterococcus faecium EF55 on the composition of avian gastrointestinal microflora. Acta Vet Brno, 2005. 72: p. 559-564.

14. Billstrom, H., et al., Virulence and antimicrobial resistance in clinical Enterococcus faecium. . International Journal of Antimicrobial Agents. 2008. 32: p. 374-377.
15. Lertworapreecha, N., K. Poonsuk, and T. Chalermchiakit, Selection of potential Enterococcus faecium isolated from Thai native chicken for probiotic use according to the in vitro properties. . Songklanakarin Journal of Science Technology. , 2011. 33: p. 9-14.

16. Ehrmann, M.A., et al., Characterization of lactobacilli towards their use as probiotic adjuncts in poultry. . J. Appl. Microbiol. , 2002. 92: p. 966-975.

17. Dunne, C.L., et al., Probiotics: from myth to reality. Demonstration of functionality in animal models of disease and in human clinical trials. Antonie Leeuwenhoek. , 1999. 76: p. 279-292.

18. Mead, G.C., Bacteria in the gastrointestinal tract of birds. , in gastrointestinal microbes and host interactions. R.I. Mackie, B.A. White, and R.E. Isaacson, Editors. 1997, Chapman and Hall. New York: p. 216-240.

19. McCarthy, J.L., et al., Double blind, placebo controlled trial of two probiotic strains in interleukin 10 knockout mice and mechanistic link with cytokine balance. . Gut, 2003. 52: p. 975-980.

20. Tannock, G.W., K., et al., Analysis of the fecal microflora of human subjects consuming a probiotic product containing Lactobacillus rhamnosus DR20. . Applied Environmental Microbiology. , 2000. 66: p. 2578-2588. 